\title{
Trapped in a Cul-de-sac? \\ The Orbit of Governance Reform in Bangladesh
}

\author{
Habib Zafarullah \\ Adjunct Professor of Sociology, University of New England, Australia
}

\section{INTRODUCTION}

In the aftermath of a revolutionary struggle against despotic rule, Bangladesh, experienced an initial enthusiasm for reform and change among politicians and attentive citizens. They aspired for a society endowed with democratic traits for people's welfare, social justice and ethical mores and a governmental system that would deliver efficient services equitably and without discrimination. Thus, since the incipient phase, intermittent attempts to reconstruct the structures and functions of government were made, some with limited consequences, others with circumscribed amplitude, and many more left undone. Contextual (social, economic, administrative) reasons may have been compelling, but undue political manoeuvres got the better of the imperatives for transformation. ${ }^{1}$ Fifty years down the line, the country remains in the quest for an effective governance system in keeping with the demands of time and sensitive to best practices in currency around the world.

Like other developing countries, Bangladesh has been induced and obligated to endure with continuous variations caused by domestic social, economic and political imperatives and, since the 1980s, by the ramifications of globalisation and the burden of meeting conditions set by international organisations and external donors. Under external compulsion, the country has had to embrace unfamiliar ways of managing the state and the public sector based on recommended practices in delivering services using new approaches and techniques, in creating an ethical and normative culture, and in employing new technology in connecting with people, institutions and the external world. $^{2}$ These have often been challenging, being contrary to traditions and conventions.

The primary purpose of this paper is to focus on the universal directions of governance reforms from the standpoint of the several elements that interweave to make governance work in a democratic ambience, notably in administrative performance, delivery of service, ethics and, most notably, the pursuit for citizen wellbeing. It follows the trajectory of governance reforms in Bangladesh during the past 50 years of

\footnotetext{
Ahmed Shafiqul Huque, 'Explaining the Myth of Public Sector Reform in South Asia: De-linking Cause and Effect' (2005) 24(3) Policy and Society 97-121; Habib Mohammad Zafarullah, 'Reflections on Civil Service Reform in Bangladesh' in Rohit Mathur, Glimpses of Civil Service Reform (ICFAI University Press 2008) 54-79.

2 See Yusuf Bangura and George Larbi, Public Sector Reform in Developing Countries (Palgrave Macmillan 2006); Victor Ayeni, Public Sector Reform in Developing Countries: A Handbook of Commonwealth Experiences (Commonwealth Secretariat 2002); Zafarullah (n 1).
} 
its nationhood, the ramifications of any achievements and the complications reform efforts encountered. The paper, to situate the Bangladesh case in the broader governance landscape will first briefly look at the conceptual factors relevant to governance, followed by ideas and innovations and how Bangladesh has fared in employing appropriate practices and encountered the complexities and challenges.

\section{THE PLACE OF GOVERNANCE REFORM IN STATECRAFT}

Governance, along with its more normative rider--'good governance', relates to goaloriented activities in government, quasi-government and non-government bodies. It is "a mode of allocating values" that is accomplished by state agencies alone or in partnership with informal entities in civil society, the private sector or the market. ${ }^{3}$ Both from ideational and practical standpoints, governance is inclusive in its scope and covers almost every strand of activity the government undertakes with relevance for the whole of society. It conveys new interpretations from structural, procedural, mechanistic and strategic angles. ${ }^{4}$

From a reform perspective, the agenda for change is fairly elaborate and intricate. With the participation of a variety of stakeholders including social groups working within networks, governance implies persuasion rather than compulsion or direct control within a framework built on coordination, collaboration and synergies between the public and private sectors. ${ }^{5}$ A conspicuous interdependency between the state and society makes for governing quality and effective policy framing and implementation. ${ }^{6}$

The approach to governance reform may take several strands as countries need to tailor their strategies to get the desired outcomes. There is no absolute right way or a set roadmap to achieving the goals of governance. Each country's needs are unique and precise and, thus, seeking to implant reform designs from another setting will be futile unless prudently tweaked. Nevertheless, there are lessons to be learned from the success stories of other countries, especially those close to Bangladesh's level of political and economic advancement.

Each of the principal targets of governance reforms-relational, institutional, operational, behavioural, ethical, legal, and technological—require a specific approach or a combination of two or more depending on priorities, contingencies, vicissitudes, capacities and resources. Relational reforms redefine the nexus between the political domain and the bureaucratic. In many ways and at many levels, the two domains overlap, and their specific distinctive operational boundaries remain eclipsed. ${ }^{7}$

3 James Rosenau, 'Governance, Order and Change in World Politics' in James Rosenau and Ernst-Otto Czempiel (eds), Governance without Government: Order and Change in World Politics (Cambridge University Press 1992) 7.

4 David Levi-Faur, 'From "Big Government" to "Big Governance"?' in David Levi-Faur (ed), The Oxford Handbook of Governance (Oxford University Press 2018).

5 Rod Hague, Martin Harrop and John McCormack, Comparative Government and Politics: An Introduction (10 ${ }^{\text {th }}$ edn, Red Globe Press 2019).

6 Francis Fukuyama, State Building: Governance and World Order in the Twenty-First Century (Profile Books 2004).

7 Joel Aberbach, Robert Putnam and Bert Rockman, Bureaucrats and Politicians in Western 
Institutional reforms focus on the rearrangement of public organisations and capacity building for better performance and efficient service delivery. It attends to procedures and norms that condition the operations of public organisations. ${ }^{8}$ Operational reforms enhance organisational procedures and consolidate internal rules for civil service management for employee efficiency and career incentives and effectively control budgeting, expenditure, financial and public procurement processes. The focus is also on strategies of policy implementation and the techniques of delivering public services. ${ }^{9}$ Behavioural reform is about changes in individual attitudes and behaviour in public organisations. However, this is hard to materialise because of deep-rooted conservatism, bureaucratic self-interest, overly demanding deportment and resistance from within. ${ }^{10}$ Related to this is ethical reform that focuses on normative and ethical values in governance systems. The task of combining compliance-based and integritypremised ethics arrangements, however, can be complicated. ${ }^{11}$ Legal reform is about embedding new laws appropriate to the demands of the time and the imperatives of moral conduct to institutionalise ethics in governance. ${ }^{12}$ To realise public ends by digital design, technological reform is now an essential item on the governance agenda. Information and communications technology (ICT) can serve as an agent in building a knowledgeable public service and an efficient public management system capable of performing to desired standards and quickly responding to societal demands.

In obtaining optimum results, all these diverse but interrelated types of reform need to be holistically approached. Disjointed or procrastinated strategies may provide shortterm effects in particular areas but will generate minimal sustainable gains in the longer run. More importantly, the uniqueness of the context in which reforms take place determines their effects. ${ }^{13}$ The nature of the state, the prevailing political order and administrative arrangements, the capacity of implementers, and the role of relevant institutions and stakeholders are critical determinants in the outcome of reforms that

Democracies (Harvard University Press 2009); B. Guy Peters, 'Globalisation, Institutions and Governance' in B. Guy Peters and Donald Savoie, Governance in the Twenty-First Century: Revitalising the Public Service (McGill-Queens University Press 2000) 29-57.

8 World Bank, Reforming Public Institutions and Strengthening Governance (World Bank 2000); World Bank, The State in a Changing World - World Development Report 1997 (Oxford University Press 1997); Bonnie Campbell, 'Governance, Institutional Reform and the State: International Financial Institutions and Political Transition in Africa' (2001) 28(88) Review of African Political Economy $155-176$.

9 Vando Borghi and Rik van Berkel, 'New Modes of Governance in Italy and the Netherlands: The Case for Activation Policies' (2007) 85(1) Public Administration 83-101.

10 Gordon Tullock, 'Dynamic Hypothesis on Bureaucracy' (1974) 19 Public Choice 127-131.

11 UNDP, 'Case Evidence on Ethics and Values on Civil Service Reform' in UNDP, Capacity Development Action Briefs (No 2, May 2007) <https://www.undp.org/content/dam/aplaws/ publication/en/publications/capacity-development/case-evidence-on-ethics-and-values-in-civilservice-reforms/Ethics-Values.pdf.> Accessed 26 January 2021.

12 World Bank, World Development Report 2017: Governance and the Law (Washington DC: World Bank 2017); See Fukuyama (n 6).

13 Merilee Grindle, 'Good Governance: The Inflation of an Idea' in Bishwapriya Sanyal, Lawrence Vale and Christina Rosan, Planning Ideas that Matter: Liveability, Territoriality, Governance and Reflective Practice (MIT Press 2012) 259-92.

Page | 114 
promote "new values and practices". ${ }^{14}$

\section{VARIATIONS IN GOVERNANCE REFORM THEORIES AND MODELS}

The movement for reform in government began in the post-World War II era when the inefficiency and ineffectiveness of the traditional form of governmental administration in managing large infrastructure projects began to be felt the world over. ${ }^{15}$ By the 1980s, with the rise of neo-liberalism, the intrusion of market forces and the growth of the private sector, the role of the government lessened, or public agencies were corporatised. ${ }^{16}$ However, despite the state rolling back, its role has not been retracted; rather the engagement of the state has been widened in social and economic spheres, especially in providing social protection to the disadvantaged, in partnering with the private sector in building infrastructure projects and in contracting out for service production and delivery. ${ }^{17}$

The orthodox way of managing government operations or Traditional Public Administration (TPA) gave way to more refined and expanded approaches that went beyond static bureaucratised and centralised structures, rule-bound procedures, and an inward-looking compass. In its place emerged a modern, open, dynamic system that focused on efficiency, performance, innovation and participation and an externaloriented perspective. ${ }^{18}$ However, several paradigmatic changes over the past decades influenced the development of different, though often overlapping, shades of governance that is more inclusive of diverse interests at societal, regional and global levels and ramifying all that matters in the life of nations and peoples. ${ }^{19}$ Scholars in the

14 Ahmed Shafiqul Huque and Habib Mohammad Zafarullah, 'Public Management Reforms in Developing Countries: Contradictions and the Inclusive State' in Ahmed Shafiqul Huque and Charles Conteh, Public Sector Reforms in Developing Countries: Paradoxes and Practices (Routledge 2014) 10.

15 Alex Ingrams, Suzanne Piotrowski and Daniel Berliner, 'Learning from our Mistakes: Public Management Reform and the Hope of Open Government' (2020) Perspectives on Public Management and Governance 1-16.

16 Claudine Kearney, Robert Hisrich and Frank Roche, 'A Conceptual Model of Public Sector Corporate Entrepreneurship' (2008) 4(3) International Entrepreneurship and Management Journal 295-313.

17 Jamie Peck and Adam Tickell, 'Neoliberalizing Space' (2002) 34(3) Antipode 380-404; D. Osbourne, 'Good Governance Initiatives in the Global Context' (1993) 2(2) Hong Kong Public Administration 107-116; Ahmed Shafiqul Huque, 'Managing the Public Sector in Hong Kong: Trends and Adjustments' (2010) 18(3) Asian Journal of Political Science 269-288; John Forrer, James Edwin Kee, Kathryn Newcomer and Eric Boyer, 'Public-Private Partnerships and the Public Accountability Question' (2010) 70(3) Public Administration Review 475-484; Emanuel Savas, Privatization and Public-Private Partnerships (Chatham House 2000).

18 Christopher Pollitt, Advanced Introduction to Public Management and Administration (Edward Elgar Publishing 2016); Christopher Pollitt, 'Be Prepared? An Outside-in Perspective on the Future Public Sector in Europe (2016) 31(1) Public Policy and Administration 3-28.

19 Martin Painter and B. Guy Peters, 'Administrative Traditions in Comparative Perspectives: Families, Groups and Hybrids' in Martin Painter and B. Guy Peters (eds), Tradition and Public Administration (Palgrave Macmillan Publishing 2010) 19-30; Christopher Pollitt and Geert Bouckaert, Public Management Reform: A Comparative Analysis. New Public Management, Governance and the NeoWeberian State ( ${ }^{\text {rd }}$ edn, Oxford University Press 2011); Manto Lampropoulou and Giorgio Oikonomou, 'Theoretical Models of Public Administration and Patterns of State Reform in Greece' 
advanced industrialised countries took the lead in advancing new ideas relevant to improving governance. About the same time, international and regional institutions, such as the United Nations, World Bank, International Monetary Fund (IMF), the Asian Development Bank and others, have provided prescriptions for managing state endeavours either alone or in collaboration with other entities, such as civil society organisations, the market and inter-organisational policy networks. ${ }^{20}$

When 'governance' was brought to the global limelight in 1992 by the World Bank, it was simple in its construction and objectives. The focus was on the nature and form of the political regime, the process of exercising authority, and the design and delivery of public policies. Later, the idea of multi-level governance was advanced and human rights, democratisation, transparency and accountability, public service capacity, participatory development, networks and partnerships were incorporated in a more comprehensive governance framework. ${ }^{21}$

While this framework was being formulated, public administration was already in the middle of going through a paradigmatic change. An innovative model-New Public Management or NPM crystallised in the 1980s and began influencing the trajectory of governance reform in the developing countries. NPM sought to eliminate or attenuate differences between public and private sector practices and make governments operate like business firms. Accountability was to be results-based rather than processdetermined. $^{22}$

Leading up to the 1980s, neoliberal governance reforms were essentially designed to build and consolidate the macroeconomic structure and establish a new model of growth. The targets were economic stability, productivity and performance, while financial liberalisation, deregulation and privatisation of underperforming state enterprises became priorities. ${ }^{23}$ This set of 'first-generation reforms' proved limited in scope and had to be reinforced by other initiatives such as building and strengthening institutions or consolidating them. Institutionalisation involved capacity building in the

(2016) 81(11) International Review of Administrative Sciences 1-21; Ewan Ferlie, 'The New Public Management and Public Management Studies' in Oxford Research Encyclopaedia of Business and

20

21 World Bank, Governance: The World Bank's Experience (World Bank 1994); Mark Schacter, Public Sector Reform in Developing Countries: Issues, Lessons and Future Directions (Canadian International Development Agency 2000); Derick W. Brinkerhoff, 'Introduction - Governance Challenges in Fragile States: Re-establishing Security, Rebuilding Effectiveness and Reconstituting Legitimacy' in Derick W. Brinkerhoff (ed) Governance in Post-conflict Societies: Rebuilding Fragile States (Routledge 2007) 1-12; R.A.W Rhodes, 'The New Governance: Governing without Government' (1996) 44(4) Political Studies 652-667.

22 Christopher Pollitt, Managerialism and the Public Services: The Anglo-American Experience (Basil Blackwell Publishing 1991); Christopher Pollitt, 'Thirty Years of Public Management Reforms: Has There Been a Pattern? (World Bank 2011) <https://blogs.worldbank.org/governance/30-years-ofpublic-management-reforms-has-there-been-a-pattern> accessed 26 January 2021; Christopher Hood, 'The 'New Public Management' in the 1980s: Variations on a Theme' (1995) 2(2/3) Accounting, Organisations and Society 93-109.

23 John Williamson, 'Democracy and the 'Washington Consensus', (1993) 21(8) World Development 1329-36.

Page | 116 
civil service and improving service delivery. Emphasis was placed on competition policies and enforcement, robust regulatory frameworks and effective property rights. More important was the inclusion of social issues in the reform agenda. ${ }^{24}$

The application and practice of governance became prominent in the 1980s with public sector reforms undertaken in many western liberal democracies. These reforms encompassed a wide range of both state- and market-centric phenomena mainly based on the ideas of neoliberalism, deliberation, partnership, networking and social inclusion. ${ }^{25}$ Following the World Bank/IMF prescribed 'second generations reforms' in 2000, the developing countries began vigorous programs of governance reforms. NPM-based reforms, entrenched in many advanced liberal countries, provided useful lessons for emulation or adaptation by the developing nations. The 'good governance' paradigm, reinforced by NPM principles, emerged as the essential agenda. ${ }^{26}$ Governance embodied the overall concern not only of governmental administration and the public policy process but also of the market, the private sector, civil society and of the environment because of its focus on fiscal, social and ecological matters. ${ }^{27}$ Its democratic inclination helped governance realise "the goals of progressive government" ${ }^{28}$ and steering function enabled governance to fulfil NPM objectives, such as effective intra-organizational relations, output- and outcome-oriented procedures through hands-on management and infusion of entrepreneurism in managerial leadership. Governance endorsed the NPM usage of business principles in managing public organisations and contracts and competition in allocating resources and delivering services. ${ }^{29}$

By the 1990s, 'good governance' became the buzzword in the global quest for better governmental administration in the developing world. However, as a paradigm, it continued to be adjusted, synthesised and reconfigured and adapted in different contexts. NPM is often considered a transitory phase in the TPA-NPG (New Public Governance) continuum. ${ }^{30}$ Several scholars have highlighted the limitations of NPM

24 Erlend Krogstad, 'The Post-Washington Consensus: Brand New Agenda or Old Wine in a New Bottle?' (2007) 50 Challenge 67-85; See also Narcis Serra and Joseph Stiglitz, The Washington Consensus Reconsidered: Towards a New Global Governance (Oxford University Press 2008); Mark Bevir and R.A.W Rhodes, Interpreting British Governance (Routledge 2003).

Mark Bevir, 'Governance' in Mark Bevir, Encyclopaedia of Governance (Sage Publishing 2007) 364381.

26 Erik-Hans Klijn, 'Public Management and Governance: A Comparison of Two Paradigms to Deal with Modern Complex Problems' in David Levi-Faur (ed), The Handbook of Governance (Oxford University Press 2012) 201-214.

27 Mark Bevir and R.A.W Rhodes, The State as Cultural Practice (Oxford University Press 2010); Habib Mohammad Zafarullah and Abu Elias Sarker, 'Public Management Reforms in Developing Countries: Towards a New Synthesis' in Nizam Ahmed (ed), Public Policy and Governance in Bangladesh: Forty Years of Experience (Routledge 2016) 42-52; Gerry Stoker, 'Governance as Theory: Five Propositions' (1998) 50(1) International Social Science Journal 17-28.

28 Habib Mohammad Zafarullah and Ahmed Shafiqul Huque, Managing Development in a Globalised World: Concepts, Processes, Institutions (CRC Press and Taylor \& Francis 2012) 162.

29 Christopher Hood, 'A Public Management for All Seasons' (1991) 69 Public Administration 3-19; Stephen P Osbourne, The New Public Governance: Emerging Perspectives in the Theory and Practice of Public Governance (Routledge 2010).

30 Stephen P Osbourne, 'The New Public Governance?' (2006) 8(3) Public Management Review 377- 
as a global application because of geographical variegation, lack of a solid theoretical foundation, overly managerialistic and instrumentalised approach and inadequate practical advantage. ${ }^{31}$

Among other ideas that emerged during the transitional phase and later, included Public Value Management (PVM), Digital Era Governance (DEG), New Public Service (NPS), Neo-Weberian State (NWS), Network Governance (NetGov) and New Public Governance (NPG). These are primarily overlapping layers of different governance forms. From a reform perspective, taken together, they form a hybrid arrangement or 'compound governance' taking elements from one another and guiding alternative reform strategies for appropriate adoption in specific situations. ${ }^{32}$ PVM stressed the social or service value function of state institutions in contrast to the economic value or profit creating behaviour by the private sector.$^{33}$ NPS is centred on serving citizens rather than customers with the public interest at its core. Its emphasis is on strategic thinking and democratic action, collaboration and collective endeavour. ${ }^{34}$

As an extension of e-Government, DEG drew on the positive effects of ICT in all operational areas of government, especially in enhancing transparency, reducing unethical practices and efficiently serving citizens. DEG features inter-institutional communicative relations, simplified agency-client interaction, digitalisation through transformative routes, engagement of non-state stakeholders in policymaking, decentralised decision making, information sharing and dissemination-all of which are critical for transparency, accountability and integrity. ${ }^{35}$

NetGov has been a response to the highly centralised, rigidly hierarchical and overly bureaucratised state structure and societal fragmentation. It creates more transparent, responsive and interactive arrangements within state structures and eclipses the conventional distinctions between government and non-state entities and connects public organisations at different levels. ${ }^{36}$ Broadly, NetGov or 'joined-up governance'

\section{7.}

31 Patrick Dunleavy, Helen Margetts, Simon Bastow and Jane Tinkler, 'New Public Management is Dead - Long Live Digital Era Governance' (2006) 16 Journal of Public Administration Research and Theory 467-494; Walter Kickert, 'Public Governance in the Netherlands: An Alternative to Anglo-American 'Managerialism' (1997) 75(4) Public Administration 731-752; Sandford Borins, 'New Public Management: North American Style' in Kathleen McLaughlin, Ewan Ferlie and Stephen Osbourne (eds) The New Public Management: Current Trends and Future Prospects (Routledge 2002) 181-194; George Frederickson and Kevin Smith, The Public Administration Primer (Westview Press 2003); Alex Matheson and Hae-Sang Kwon, 'Public Sector Modernisation: A New Agenda' (2003) OECD Journal on Budgeting 3(1) 7-23.

32 Colin Crouch, Capitalist Diversity and Change: Recombinant Governance and Institutional Entrepreneurs (Oxford University Press 2005).

33 Mark Moore, Creating Public Value: Strategic Management in Government (Harvard University Press 1995); Gerry Stoker, 'Public Value Management: A New Narrative for Networked Governance?' (2006) 36(1) American Review of Public Administration 41-57.

34 Robert Denhardt and Janet Denhardt, 'The New Public Service: Serving Rather than Steering' (2000) 60(6) Public Administration Review 549-559.

35 Dunleavy (n 31); Habib Mohammad Zafarullah and Abu Elias Sarker (n 27).

36 Mark Bevir, 'Governance as Theory, Practice and Dilemma' in Mark Bevir (ed) The SAGE Handbook

Page | 118 
involves a wide body of stakeholders through partnership, synergy and inclusion, it makes them part of a democratised policy process. ${ }^{37}$

NWS reinvented Weber in governance and emphasised the supremacy of the state. It recommended new forms of administrative law within the ambit of representative democracy supported by a professionalised and politically neutral bureaucracy with a public service ethos. A basic code guiding citizen-state relations would ensure equality for everyone and protection against arbitrary state actions. ${ }^{38}$

NPG builds upon TPA and NPM but differs with both in some ways, the most significant departure being its shift from hierarchical-bureaucratised administration and management concerns (managerial judgment and contractual procedures) to citizen needs. In Osborne's words, "NPG has become the dominant regime of public policy implementation and public services delivery, with a premium being placed upon the development of sustainable public policies and public services and the governance of interorganizational relationships. $" 39$

All of the above conceptual 'models' have had an important impact on the design and application of governance reform in both developed and developing countries. However, many countries accepted parts of different models and tailored them according to their needs, the reform perspectives of the leadership, availability of resources and the capacity of implementing agencies. The United Nations endorses, "a hybrid approach to public sector reform that embraces adaptive responses to complexity...". 40

\section{THE TRAJECTORY OF REFORMS IN BANGLADESH}

The change imperative was evident right after Bangladesh achieved its nationhood. The new political leadership, wary of the imperious role of the bureaucracy during preindependence times, was bent upon transforming the inherited administrative landscape. The bureaucracy encultured during the colonial and post-colonial eras was considered elitist, illiberal, overly formalistic, resistant to change and condescending of political control. ${ }^{41}$ The shift from a highly centralised presidential system to one

of Governance (SAGE Publications 2011) 1-16; Kim Junki, 'Networks, network governance, and networked networks' (2006) 11(1) International Review of Public Administration 19-34.

37 Tom Christensen and Per Laegried, 'The Whole-of-Government Approach to Public Sector Reform' (2007) 67(6) Public Administration Review 1059-1066; Bevir (n 25); Christopher Hood, 'The Idea of Joined-Up Government: A Historical Perspective' in Vernon Bogdanor (ed), Joined-Up Government (Oxford University Press 2005) 19-42.

38 Christopher Pollitt and Geert Bouckaert (n 19).

39 Stephen P Osbourne (n 29) 414.

40 UNDP, From Old Public Administration to the New Public Service - Implications for Public Sector Reform in Developing Countries (United Nations Development Programme 2015) 15-16.

41 Habib Mohammad Zafarullah, 'Administrative Reform in Bangladesh: An Unfinished Agenda' in Ali Farazmand (ed), Administrative Reform in Developing Nations (Praeger Publishers 2002); Habib Mohammad Zafarullah, 'Shaping Public Management for Governance and Development: The Case of Pakistan and Bangladesh' (2006) 9(3) International Journal of Organization Theory and Behaviour 
built upon Westminster nuances entrusted the political executive with complete control over the administrative system. By default, many who had served in the Civil Service of Pakistan (CSP) and other provincial generalist services were now inducted into the newly organised national bureaucracy. They were unfamiliar with parliamentary practices vis-à-vis public administration and, thus, resisted further moves to strip them of their privileged position and authority in the governmental system. An atmosphere of unease prevailed when a high-profiled body-the Administrative and Services Reorganization Committee (ASRC) went through the routine of recommending radical measures influenced by the contemporary British Fulton Committee reforms. It confirmed existing concerns about various problems surrounding the bureaucracy. Fearing the proposed measures would compromise their exclusive status and power, the generalists felt despondent and manifested a negative stance vis-à-vis the regime. ${ }^{42}$ The bureaucracy obtained a reprieve as the government shelved the ASRC report mainly because of social tensions, the economic downturn and political antagonism as well as the discontent brewing within the upper ranks of the civil service. The regime had to mark time as its priority shifted to finding solutions to more pressing issues, mainly relating to the economy and in maintaining itself in power amidst internal and external threats. ${ }^{43}$

Ironically, while a political government failed to produce practical solutions to familiar problems in managing government, two stints of military rule brought about systemic order by reorganising the bureaucracy and streamlining administrative functions. ${ }^{44}$ However, from political, economic and ethical perspectives, more needed to be done. The quasi-democratic regime with the backing of the military introduced policy reforms for better economic performance and improved governance following the directions of the Bretton Woods institutions, which by the 1980s had imposed conditions on developing countries as a requirement for obtaining aid. ${ }^{45}$ However, the rush towards establishing institutions and practices often went wrong, weakening political and economic arrangements. The externally imposed economic policy changes -the structural adjustment programs-focused on demand management and financial stabilisation that covered trade liberalisation, foreign direct investment,

352-377; Hamza Alavi, Capitalism and Colonial Production (Croom Helm 1982).

42 M.M Khan and Habib Mohammad Zafarullah, 'Bureaucratic Intransigence and Administrative Reforms in Bangladesh' in Gerald Caiden and Heinrich Seidentopf (ed), Strategies for Administrative Reform (Lexington Books 1982) 139-152; Emajuddin Ahmad, Bureaucratic Elites in Segmented Economic Growth: Pakistan and Bangladesh (Dhaka University Press 1980).

43 R. Jahan, 'Bangladesh in 1973: Management of Factional Politics' (1974) 14(2) Asian Survey 125135; T. Maniruzzaman, 'Bangladesh in 1974: Economic Crisis and Political Polarisation' (1975) 15(2) Asian Survey 117-128.

44 Habib Mohammad Zafarullah, 'Public Administration in the First Decade of Bangladesh: Some Observations on Developments and Trends' (1987) 27(4) Asian Survey 459-476.

45 Jean Grugel, Democratisation: A Critical Introduction (Palgrave Macmillan 2001).

Page $\mid 120$ 
deregulation, and privatisation. ${ }^{46}$ Implementation, however, was tardy and ineffective caused by "a suffocating regulatory environment, and obstructionism, incompetence, and downright venality in the bureaucracy". ${ }^{47}$ Indeed, governance was in a bad way and needed thorough reform.

The successive 'democratic' regimes that followed since 1991 made a pretence of reform. The UNDP, IMF and World Bank overtures were ignored, while the reports of government-created reform bodies-the Administrative Reform Committee (ARC) and the Public Administration Reforms Commission (PARC), found little appreciation by their initiators. ${ }^{48}$ Evasive political support and bureaucratic circumvention deterred any possibility of change happening. The current trends in governance reform elsewhere had very little influence on the political leadership or the policymakers in the country. Indeed, a political approach to governance has remained inconspicuous, the governments being indifferent of political, institutional and technological dimensions of governance. Rather, politically bureaucratised style and technical orientation influenced reform efforts. A recent study contended that the "bureaucracy, in effect, colluded with the political elites in political accumulation and were able ultimately to thwart [sensible] reform initiatives". ${ }^{49}$ Yet, external pressure for wideranging reform kept stiffening, ${ }^{50}$ as domestic demands for improving governance heightened. A World Bank report argued for greater intervention in governance reform (rule of law, security, and coordination) and freeing the policy process from elite capture, promoting human development and controlling climate change. ${ }^{51}$ In Bangladesh, with intensified politicisation and poor performance, the image of the civil service kept drowning as "unbridled corruption, poor governance, and confrontational politics" along with "the near absence of the rule of law and an ever weakening law enforcement apparatus" and "unaccountable service providers" 52 ate into the nation's

46 World Bank, Bangladesh: From Stabilisation to Growth (World Bank 1994).

47 Clare Humphrey, Privatisation in Bangladesh: Economic Transition in a Poor Country (Westview Press 1990) 136.

48 UNDP, Public Administration Sector Study (UNDP Dhaka 1993); World Bank (n 46); World Bank, Bangladesh: Government that Works - Reforming the Public Sector (World Bank 1996); ADB, Proposed Loan and Technical Assistance Grant People's Republic of Bangladesh: Strengthening Governance Management Project (Asian Development Bank 2010).

49 Abu Elias Sarker and Habib Mohammad Zafarullah, 'Political Settlements and Bureaucratic Reforms: An Exploratory Analysis Focusing on Bangladesh' (2019) 55(2) Journal of Asian and African Studies 235-253, 10.

50 World Bank, Taming Leviathan: Reforming Governance in Bangladesh: An Institutional Review (World Bank 2000); World Bank, Bangladesh: Strategy for Sustained Growth (World Bank 2007); ADB (n 48).

51 World Bank, Bangladesh Development Update: Powering the Economy Efficiently (Dhaka: World Bank Bangladesh 2018).

52 Ali Riaz, 'Bangladesh: A 'Weak State' with Multiple Security Challenges' in T.V Paul (ed) South Asia's Weak States: Understanding Regional Insecurity Predicament (Stanford University Press 2010) 
fabric. Indeed, in recent years, integrity in various social and economic sectors has fallen into its lowest ebb. ${ }^{53}$

During the tenure of the two political parties in power (the Bangladesh Nationalist Party-BNP and the Awami League-AL), the focus has been on updating rules and regulations relating to trivial age and qualification of recruits and civil service examination matters, instead of enhancing the quality of the internal labour market, ridding the selection process of aberrant methods and promoting the merit principle against the quota system in recruitment. ${ }^{54}$ The capacity development regime for civil servants was streamlined in the wake of the Public Administration Training Policy of 2003, but weak strategies have hindered implementation. ${ }^{55}$ Similarly, changes to the promotion system may have been attempted in good stead, but it lacks objectivity and leans heavily towards non-merit factors and thus overwhelmingly benefits the incompetent and inefficient. ${ }^{56}$ Some new additions to the administrative arrangements, such as citizens' charter, one-stop service centres, consumer protection, freedom of information, corporatisation of public agencies, contracting-out or outsourcing, egovernance and digitalisation of services, performance audit, public-private partnership, etc.) are related to NPM or the other conceptualisations, but the way they have been devised and are being administered have produced ineffective results. ${ }^{57}$

To be more specific about the course of governance changes, we can refocus on relational, institutional, operational, behavioural, ethical, legal, and technological reforms in the context of Bangladesh.

\section{A. Relational Reforms}

The relation between politics and administration is quite ambiguous in Bangladesh.

\section{1-264, 247.}

53 Habib Mohammad Zafarullah and Ahmed Shafiqul Huque, 'Corruption and its Control: The Pursuit of Probity in Bangladesh' in Krishna Tummala (ed), Corruption in the Public Sector: An International Perspective (Emerald Publishing 2021) 57-77; Salahuddin Aminuzzaman and Sumaiya Khair, Bangladesh National Integrity System Assessment (Transparency International 2014).

A.M.M.S Ali, The Lore of the Mandarins: Towards a Non-Partisan Public Service in Bangladesh (Dhaka University Press 2002); A.M.M.S Ali, Bangladesh Civil Service: A Political-Administrative Perspective (Dhaka University Press 2011); IGS, Institutes of Accountability: The Public Service Commission - A Policy Note (Institute of Governance Studies, BRAC University 2008); TIB, Bangladesh Public Service Commission: A Diagnostic Study (Transparency International Bangladesh 2007).

55 Md Khurshid Iqbal Rezvi, Effectiveness of the Public Administration Training: A Study on the Administrative Cadre Service in Bangladesh (Master of Public Policy Thesis, KDI School of Public Policy and Management 2013); UNDP, Cost Effectiveness of Training and Course Curricula at BPATC: Developing Civil Service for $21^{\text {st }}$ Century Administration (Government of Bangladesh and UNDP 2007).

56 Habib Mohammad Zafarullah, M.M Khan and M.H Rahman, 'The Civil Service System of Bangladesh' in John Burns, Bidhya Bowornwathana (eds), Civil Service Systems in Asia (Edward Elgar 2001); Salahuddin Aminuzzaman, Career Planning of Bangladesh Civil Service (MPPG Policy Paper, North South University 2013); A.M.M.S Ali, Civil Service Management in Bangladesh: An Agenda for Policy Reform (University Press Limited 2010).

57 Pan Suk Kim and Mobasser Monem, 'Civil Service Reform in Bangladesh: All Play but Hardly any Work' (2009) 31 9(1) Asia Pacific Journal of Public Administration 57-70.

Page | 122 
Historically, bureaucratism has had pre-eminence in running the state. This was evident during pre-independence days and for nearly one and a half decades since independence when the country was under military or quasi-political rule. The relationship between the bureaucracy and the ruling group, perhaps unholy, was mutually supportive. Ironically, with political regimes in power since 1991, this has continued, although democracy demands public officials are subject to control and accountability. Invasive neo-patrimonial influence, together with excessive politicisation of the bureaucracy, has diluted the value of accountability. ${ }^{58}$ The inordinate penchant for regime maintenance by the ruling party has pushed it to rely on the bureaucracy for support, without which retention of power may be difficult. Thus, relational reform has meant keeping the bureaucracy in geniality by giving public servants frequent pay raises and lucrative perks.

The relationship between the political and bureaucratic spheres needs to be clearly defined. That public policymaking is not the exclusive domain of the politicians nor of the bureaucrats must be understood and acknowledged. Similarly, a delineated political space for citizens, policy stakeholders and the private realm will expand the inclusivity of the state, as will the incorporation of social and environmental issues into the policy agenda. The major political parties need to have clear thinking about these nexuses and tone down on the degree of political patronage as it relates to the bureaucracy. ${ }^{59}$ Similarly, the patronising attitude of public officials over citizens, an offshoot of the patron-client syndrome ${ }^{60}$ needs to be tapered off to make the administration citizencentred.

Vision 2021 of the incumbent government does enunciate some of the areas that would connect the state with the people and enhance their status as citizens through the rule of law, freedom of expression, equity and fairness, citizen access to services, social justice, environmental protection, equal opportunities and women's empowerment. ${ }^{61}$ The National Sustainable Development Strategy 2010-2021, if implemented correctly, has the scope of creating an enabling environment for state-civil society exchanges, government-business mutuality, and public-private synergy. ${ }^{62}$ While political control of the civil service is crucial in a democracy, intense politicisation is unwarranted for the sake of objectivity, neutrality and professional conduct of the bureaucracy that has been hindering sound administration and thwarting reform initiatives relating to NPM. Vision 2021 acknowledges this and emphasises the primacy of keeping the civil service

\footnotetext{
${ }^{58}$ Habib Mohammad Zafarullah and M.M Khan, 'The Bureaucracy in Bangladesh: Politics within and the Influence of Partisan Politics' in Ali Farazmand (ed), Handbook of Comparative and Development Public Administration (2 $2^{\text {nd }}$ edn, Marcel Dekker 2001) 981-997.

${ }^{59}$ UNDP, Building a $21^{\text {st }}$ Century Public Administration in Bangladesh (UNDP Bangladesh 2007); Noore Alam Siddiquee, 'Human Resources Management in Bangladesh Civil Service: Constraints and Contradictions (2003) 26(1) International Journal of Public Administration 35-60; Habib Mohammad Zafarullah and M.M Khan (n 58).

${ }^{60}$ Ali (n 54).

${ }^{61}$ Government of Bangladesh, Perspective Plan of Bangladesh 2010-21: Making Vision 2021 a Reality (Government of Bangladesh 2010).

${ }^{62}$ Government of Bangladesh, National Sustainable Development Strategy 2010-21 (Government of Bangladesh 2010).
} 
free from partisan influence. ${ }^{63}$ However, the Civil Service Act of 2018, does not focus on bureaucratic anonymity, neutrality or non-partisanism nor is it specific about serving the citizens; instead, it protects public officials against criminal charges. ${ }^{64}$

\section{B. Institutional Reforms}

In response to the imperatives of neoliberalism and external donor influences, institutional reforms within the governmental machinery and beyond have come about but in relatively low measure. The steady growth of the economy has been fostered by some degree of structural transformation, innovation, entrepreneurship and private investment. With the dominance of market forces, changes in the dynamics of government-business and public-private sector engagements are noticeable. Important reforms in public procurement, fiscal reporting, audit management and integrity surveillance have led to improvements in financial management. The Financial Management Reform Programme initiated in 2003 has gone on to streamline government accounting, while the 'Strengthening Public Expenditure Management Program' covered public auditing. The Public Finance Management Reform Strategy (2016-2021) is focused on creating an enabling environment for fiscal discipline, prioritised resource allocation, efficient resource use and service delivery, and external scrutiny, transparency and accountability. ${ }^{65}$

The move towards economic liberalisation in the late 1970s through to the 1990s provided the ground for disinvesting in the public sector, privatisation of hitherto nationalised industries and provision of incentives for private sector growth. Several policy measures and macroeconomic adjustments despite occasional hiccups stabilised the economy, but governance-related issues continue to serve as deterrents. ${ }^{66}$ Indeed, the success of past reform efforts in the financial sector has often been impeded by a laid-back reform posture, systemic ambiguities, limited capacity, bureaucratic inertia and indecision, and "opportunistic short-term political gains". ${ }^{67}$ Despite remarkable gains in social indicators, development snags and pro-poor growth have been hamstrung by poor governance.

At the political level, the return of parliamentary democracy did little to change the nature of public administration, except for the prime minister taking on the role of head of government and concentrating more power in her office. The 'Rules of Business' and the way the ministries worked and interacted among themselves and controlled departments and subordinate offices remained unchanged. The statutory bodies, supposed to be autonomous, continued to be dominated by the ministers. The courts

${ }^{63}$ Government of Bangladesh (n 61).

${ }^{64}$ Public Service Act 2018 (Bangladesh).

65 Government of Bangladesh, Public Financial Management (PFM) Action Plan 2018-23 to Implement the PFM Reform Strategy 2016-21 (Government of Bangladesh 2018).

66 See Wahiduddin Mahmud, Sadiq Ahmed and Sandeep Mahajan, Economic Reforms, Growth and Governance: The Political Economy Aspects of Bangladesh's Development Surprise (World Bank 2008).

67 World Bank, Strengthening Public Expenditure Management Program - Strengthening Auditor General's Office (Report No 142700, World Bank 2020) 1.

Page $\mid 124$ 
have remained an appendage of the executive with minimal scope to operate on their own. Judicial review of administrative actions has been rare. ${ }^{68}$ Parliament, overwhelmingly controlled by the ruling coalition since 'democracy' was restored, has seldom deliberated on governance issues or made concerted efforts to scrutinise executive action in the same rigour and force as it does in berating the opposition. ${ }^{69}$ Its assertive role in influencing policy development and policy evaluation has been misplaced with parliamentary committees being passively active (regular and procedural, but deviant) in realising their objectives. ${ }^{70}$ Despite some positive institutional changes in parliamentary practice (prime minister's question time, replacing ministers as chairs of the standing committees (SC), expansion of SC's powers, committee scrutiny of bills, live telecast of proceedings, "[v]arious structural, procedural, behavioural and political factors tend to discourage the parliament from becoming an effective institution". ${ }^{71}$ Whatever reforms have been achieved need to be consolidated to make parliament more productive but less partisan.

One of the major governance reforms undertaken with wide ramifications was administrative decentralisation initiated by a military ruler. In some measure, central control over field administration was diluted with the emergence of representative bodies at the local level handling developmental functions, though masterminded by locally deployed officials directly controlled by the national administration. This created a grey area in central-local relationship and undermined the power of democratically elected local institutions. ${ }^{72}$

Structural reform of the civil service, begun and consolidated under military regimes, have been left untouched by successive regimes, except for a few cosmetic alterations. Statutory bodies, meant to be at arms-length, remain under executive vigilance and control unable to uphold their autonomous status. Thus, constitutional bodies, such as the Public Service Commission, Election Commission, and Comptroller and AuditorGeneral, generally work with their wings clipped being overseen by people toeing the ruling party line. ${ }^{73}$ The creation of the Anti-Corruption Commission for fighting corruption and the Information Commission for ensuring greater transparency in public

68 Habib Mohammad Zafarullah, 'The Governmental Machinery in Bangladesh' in Nizam Ahmed (ed), Forty Years of Public Administration and Governance in Bangladesh (University Press Limited 2015).

69 Rounaq Jahan and Inge Amundsen, 'The Parliament of Bangladesh: Representation and Accountability', CPD-CMI Working Paper No 2 (Centre for Policy Dialogue, 2012); S.S Islam, 'Good Governance and Political Culture: A Case Study of Bangladesh' (2016) 24(2) Intellectual Discourse 245-271.

70 M. Maniruzzaman, 'Parliamentary Democracy in Bangladesh: An Evaluation of the Parliament during 1991-2006' (2009) 47(1) Commonwealth \& Comparative Politics 100-126; Muhammad Mustafizur Rahman, 'Parliament and Good Governance: A Bangladeshi Perspective' (2008) 9(1) Japanese Journal of Political Science 39-62.

71 Nizam Ahmed, 'Parliament and Democratic Consolidation in Bangladesh (2011) 26(2) Australasian Parliamentary Review 53-68, 63.

72 Ahmed Shafiqul Huque and Pranab Kumar Panday, 'Local Institutions and Governance in Bangladesh: Progress, Pitfalls and Potentials' in M.A Khan and Habib Mohammad Zafarullah (eds) Whither Bangladesh: Accomplishments, Opportunities, Challenges and the Future (South Asian Journal, Special Issue 2018).

73 Saadat Husain, 'Constitutional Bodies in a Democratic Polity' The Daily Star (Dhaka, 12 March 2014). 
affairs have been two significant initiatives in governance reform, but both bodies have been underperforming. ${ }^{74}$ Human rights surveillance remains at a low level despite the installation of a Human Rights Commission. ${ }^{75}$

\section{Operational Reforms}

According to the Worldwide Governance Indicators (WGIs), governmental effectiveness $^{76}$ is fairly weak in Bangladesh. It currently ranks at 147 among 193 countries with a score of -0.74 points, much lower than the South Asian median. ${ }^{77}$ The government acknowledged that low public administration capacity, occasional weaknesses in economic management and persistent corruption lie at the heart of the overall shortcoming in national governance. As a result, the public sector has not been able to play as effective a role as could have been the case in providing services and creating an environment for growth. ${ }^{78}$

Both the $6^{\text {th }}$ and $7^{\text {th }}$ Five Year Plans identified the civil service system, local governance, public-private partnership arrangement and fiscal management processes as operational problem areas needing rectification. ${ }^{79}$ To these can be added the perennial issue of program and project implementation and, to cap everything, enduring bureaucratisation triggered by hierarchical and procedural rigidity, red-tape, formalism, procrastination, obstinacy and responsibility avoidance. Organisational dysfunctionality and procedural complexities complicate government operations due to misallocation of resources, misplaced expertise, functional overlap, incoherent rule application, flawed inter-agency coordination or consultation, and decision delays. ${ }^{80}$ The limitations of overarching policies in many areas of governance, complemented by the constrained application of procedural norms and best practice are notable. This has been despite there being a plethora of rules directing public officials to discharge their obligations in predetermined ways. The machinery of government operates according to constitutional principles, several statutory guidelines, regulations,

74 Harold Baroi and Shawkat Alam, 'Operationalising the Right to Information Act through e-governance in Bangladesh: Challenges and Opportunities' (2020) International Journal of Public Administration <https://doi.org/10.1080/01900692.2020.1747489> accessed 26 January 2021 (accepted for publication); Nurul Sakib, 'Institutional Isomorphism of Anti-Corruption Agency: The Case of AntiCorruption Commission in Bangladesh (2020) 5 Chinese Political Science Review 222-252; Salahuddin Aminuzzaman and Sumaiya Khair (n 53).

75 Human Rights Watch, World Report 2020: Events of 2019 (Human Rights Watch, 2020) 61-64 <https://www.hrw.org/sites/default/files/world_report_download/hrw_world_report_2020_0.pdf> accessed 26 January 2021.

76 'Governmental effectiveness' "captures perceptions of the quality of public services, the quality of the civil service and the degree of its independence from political pressures, the quality of policy formulation and implementation, and the credibility of the government's commitment to such policies" 'Bangladesh: Government Effectiveness' (theglobaleconomy.com) <https://www.theglobaleconomy.com/Bangladesh/wb_government_effectiveness/> accessed 05 March 2021.

77 World Bank (n 67).

78 Government of Bangladesh, Sixth Five Year Plan 2011-15: Accelerating Growth and Reducing Poverty (Government of Bangladesh 2011) 31.

79 Ibid; Government of Bangladesh, Seventh Five Year Plan 2016-20: Accelerating Growth, Empowering Citizens (Government of Bangladesh 2016).

80 Habib Mohammad Zafarullah (n 68).

Page $\mid 126$ 
executive directives and instruction manuals. Some achievements are apparent in alleviating poverty, augmenting budgetary resource flow, increasing primary school enrollment and attaining gender equity at both primary and secondary levels, reducing infant and maternal mortality, managing disasters and climate change through adaptation, mitigation and climate financing mechanisms, widening the social protection of the poor and disadvantaged, easing access to public services through national identification cards, and promoting innovation in the bureaucracy for improved service delivery. These have been effected through specific policies relating to education, health, social security, gender and women, science and technology, information access, anti-corruption and so on, all directly or indirectly relevant to governance issues, primarily social inclusion, transparency and accountability. ${ }^{81}$

Operational reforms focus on capacity development in the public sector, program and results-based approach in budgeting and planning monitoring/evaluation, egovernance and e-service mechanisms, procurement and contracting-out schemes, fiscal and tax management, public service delivery methods. However, most times, their implementation has been sluggish and outcome mixed. Several Acts, manuals and guidelines exist that instruct how specific agencies and individuals are to act, interact and react in the realisation of their organisational objectives. ${ }^{82}$ However, these have not always been instrumental in securing compliance in operational terms.

\section{Behavioural Reforms}

The colonial legacy still lingers on in Bangladesh's administrative system. Longstanding cultural beliefs influence civil servants' role in society and their approach to administrative pursuits. The contradiction between the dispassionate application of formal rules and deviation from official obligations for personal, kinship or political reasons leaves the bureaucracy in a quagmire. Historically, the 'selfinterest' approach of bureaucrats or inter-cadre (especially specialists vs generalists) antagonism created tensions and led to goal displacement conflicting, as it did, with the overall mission of the civil service. ${ }^{83}$ This proved detrimental to bureaucratic integration, dented cohesion and worked against professionalism.

The obsession with rule-based operations and manifestations of power and authority in a closed and secretive post-colonial bureaucracy featuring sub-system autonomy, uneven superior-subordinate relationship and top-down decision-making are at odds with governance-centred reforms that emphasise democratic controls, transparency and openness, integrity, policymaking equity, citizen focus, consultation and collaboration, and protection of the public interest. While none of the reform initiatives of the past targeted the behavioural dimension per se, several prior and existing maxims ${ }^{84}$ support

\footnotetext{
Government of Bangladesh (n 78); Government of Bangladesh (n 79).

Habib Mohammad Zafarullah (n 68).

Habib Mohammad Zafarullah and M.M Khan (n 58).

4 Key ones include: The Government Servants (Conduct) Rule 1979; Government Servants (Discipline \& Appeal) Rule 1985; Government Servants (Special Provisions) Ordinance 1979; Public Employees Discipline (Punctual Attendance) Ordinance 1982; Prescribed Leave Rule 1959; Government Servants (Discipline and Appeal) Rules 2018.
} 
positive bureaucratic demeanour and performance, including conduct and discipline, information sharing, reporting, incentives and probity. ${ }^{85}$ These rules cover the entire career of civil servants and range from post-recruitment responsibilities to participating in training programs to conducting themselves properly.

From a behavioural and attitudinal perspective, "a majority of civil servants is satisfied with their job, [are] trusting towards their colleagues, committed to staying in the public sector and motivated to serve the public interest...[but]...only just over half of [them] are motivated to work hard" ${ }^{86}$ The main stimulating factors are accelerated promotion, periodic salary increases ${ }^{87}$ and unconventional perks, such as soft car and subsidised housing loans and mobile phone bill payment. ${ }^{88}$ Needless to say, legislations, policies, rules or procedures cannot really change the actions and attitudes of public officials by compulsion overnight. The age-old ideas and attributes ingrained in the bureaucratic mind linger (even among those not bred in those norms) through enculturation-- a continuous process of transferring cultural attributes from the oldguards to the new. That way, newcomers, over time, assimilate the behavioural attributes of their predecessors. ${ }^{89}$ Behavioural reform, thus, has not happened or is improbable as time-honoured perceptions and orientations are entrenched in the bureaucratic psyche.

\section{E. Ethical Reforms}

As is widely known, one of the WGIs in which Bangladesh ranks fairly low is "control of corruption'-with a score in 2019 of -0.99 the country ranked at 159 among 193 countries. ${ }^{90}$ It ranked 146 (out of 180) with a score of 26/100 in Transparency International Corruption Perception Index. ${ }^{91}$ Corruption has taken many forms in the present neo-liberal economic environment with the scope for unethical practices widening. It has engulfed the business sector, the bureaucracy, defence and coercive forces and even political circles. ${ }^{92}$ Incidence of corruption is attributed to venal state capture by devious elements, partisan decisions at the highest levels, unsound

85 Government of Bangladesh, Annual Report of MOPA (Government of Bangladesh 2018).

86 Jan-Hinrik Meyer-Sahling, Christian Schuster, Kim Sass Mikkelsen, Taiabur Rahman, Kazi Maruful Islam, Ahmed Shafiqul Huque, Fanni Toth, Civil Service Management in Bangladesh (UK Department of International Development 2019) 11.

87 Habib Mohammad Zafarullah, M.M Khan and M.H Rahman (n 56).

88 J U Haroon, 'Civil Servants Get Stunning Benefits' The Financial Express (Dhaka, 19 August 2019).

89 Habib Mohammad Zafarullah, 'Bureaucratic Elitism in Bangladesh: The Predominance of Generalist Administrators' (2007) 15(2) Asian Journal of Political Science 161-173; Habib Mohammad Zafarullah, 'Bureaucratic Culture and the Social-Political Connection: The Bangladesh Example' (2013) 36 (13) International Journal of Public Administration 932-939; Ishtiaq Jamil, 'Administrative Culture in Bangladesh: Tensions Between Tradition and Modernity' (2002) 12(1) International Review of Sociology 93-125.

90 Global Economy, Control of Corruption - Country Rankings (The Global Economy 2020). Available at <https://www.theglobaleconomy.com/rankings/wb_corruption> accessed 26 January 2021.

91 Transparency International, Bangladesh, In Corruption Perception Index 2019 (Transparency International 2020) <https://www.transparency.org/en/cpi/2020/results/bgd> accessed 26 January 2021.

92 Salahuddin Aminuzzaman and Sumaiya Khair (n 53); Iftekharuzzaman, Fighting Corruption in Bangladesh: From One Myth to Another? (Transparency International 2007).

Page | 128 
accountability structures and procedures, and bureaucratic non-compliance to the principles of probity. ${ }^{93}$

This is one reform area where substantial inroads have been attempted but seldom providing the desired results. Following up on the United Nations' 'Convention Against Corruption' of 2003, several measures have been put in place, such as the AntiCorruption Act (2004), Public Procurement Act (2006), National Integrity Strategy (2008), Right to Information Act (2009), Public-Interest Information Disclosure Act (2011), Money Laundering Act (2012), and Finance Act (2018) while other exiting laws (some dating to colonial times) have been updated or amended to counter corrupt practices in both the public and private sectors. Other measures, including the Government Auditing Standards, Code of Ethics, two other Codes relating to auditing and public accounts, have the potential to ensure transparency of and accountability in government operations. The institutional spin-off of these actions has been the formation of the Anti-Corruption Commission, the Information Commission, Financial Intelligence Unit of the Central Bank, and Central Procurement Technical Unit, etc. As emphasised before, codifying operational ethics in and beyond government is a complex task, while instilling a culture of ethics and morality in public governance is even harder. Yet, these are important for enhancing the credibility of the government, raising the bureaucracy's public image and building trust among citizens.

\section{F. Legal Reforms}

Ethical reforms cannot be institutionalised unless accompanied by reforms of the legal system of the country. The judiciary and the framework under which it operates must be robust enough to administer justice by prudently interpreting laws and upholding citizens' rights without fear or favour. Constitutionalism and the Rule of Law are preeminent in public governance without which democratic practice will remain spurious. The constitution affirms the independence of the judiciary, but the fairness of the justice system has been compromised by undue political interference, condescending patronage networks, prolonged or delayed trials and pervasive corruption. Judges giving verdicts "unfavorable to the government risked transfer to other jurisdictions" create trepidation and misgivings in the legal community. ${ }^{94}$ The separation of the judiciary from executive control formalised by a non-political caretaker government in 2007, the creation of two separate magistracies for judicial and executive functions and the requirement that president consults with the Supreme Court while exercising control over the judicial service were significant initiatives. ${ }^{95}$ Other

93 Iftekharuzzaman, 'Corruption: Towards Kleptocratic State Capture' The Daily Star (Dhaka, 1 January 2014); Ahmed Shafiqul Huque, 'Accountability and Governance: Strengthening Extra-Bureaucratic Mechanisms in Bangladesh' (2011) 60(1) International Journal of Productivity and Performance 5974; Habib Mohammad Zafarullah and Ahmed Shafiqul Huque (n 53).

94 USDS, 2019 Country Reports on Human Rights Practices: Bangladesh (US Department of State, 2019) $\quad 8 \quad<$ https://www.state.gov/reports/2019-country-reports-on-human-rightspractices/bangladesh/> accessed 26 January 2021. See also Abdul Alim, 'Corruption in Civil Litigation System: An Approach to Judicial Reform in Bangladesh (2018) 9(2) Asian Journal of Law and Economics 1-11. 
reforms included the amendment of the age-old Criminal Procedure Code of 1898, vesting of judicial powers upon executive magistrates through the Mobile Court Ordinance (2007) and the creation of 'Metropolitan Courts of Sessions' in Dhaka and Chittagong for the rapid dispensation of justice. ${ }^{96}$

The 1972 Constitution had provided for an Ombudsman, but even after almost 50 years, this has remained illusory. Successive governments promised of its initiation but backtracked. Perhaps, it would have served as an 'independent' mediator in resolving government-citizen disputes and promoting natural justice. A Law Reforms Commission exists but not quite effective in impressing upon the political leadership to go for meaningful reform of the legal regime for sound governance.

\section{G. Technological Reforms}

Bangladesh has been effectively using technology in managing the operations of government. Notable achievements are the projects and programs in e-governance, eservice, e-commerce, e-marketing, e-banking, e-procurement and mobile phone connectivity. The country is now connected to the information superhighway, and broadband networks and smartphones link citizens to the state. Local service centres enabled by ICT serve the people in different ways-providing access to governmental information, applying for and getting documents (various kinds of certificates, passports, land mutation, etc.), paying utility charges, and permitting two-way interaction between service providers and users. $^{97}$ Paper-based governmental operations have been opaque, tardy and amenable to malpractices; now these are transparent, faster and less prone to corruption. Indeed, Bangladesh currently ranks among the top 10 least developed countries in e-governance encompassing poverty alleviation, health, education, agriculture, and public administration. It is now among the high EGDI countries and making "impressive advancements in online services provision despite having middle or low levels of infrastructure development". ${ }^{98}$

While these have been admirable achievements that bode well for effective governance, several laws relevant to the application of technology have adverse implications for freedom of expression. For instance, the 'Digital Security Act' and the excessive power granted to the coercive and regulatory agencies in capriciously enforcing its stipulations by persecuting political opposition and silencing criticisms against the government or its policies have invited condemnation. ${ }^{99}$

Monitor 2007) <https://www.loc.gov/law/foreign-news/article/bangladesh-judiciary-separated-fromexecutive-control/> accessed 26 January 2021.

96 N. R. Anzara, 'Independence of Judiciary: A Bird's Eye View (2016) (Bangladesh Law Digest, 13 August 2016) <https://bdlawdigest.org/independence-of-judiciary-in-bangladesh.html> accessed 26 January 2021.

97 Md Gofran Faroqi, 'An Assessment of e-Government: Case Study on Union Digital Centres (UDC) in Bangladesh' (2015) 1(1) Australian Journal of Sustainable Business and Society 84-96.

98 United Nations, E-Government Survey 2020 (Department of Economic and Social Affairs, UN 2020) 21; K. Kosenkov, 'UN E-Government Development Index' (UN, 2018) <https://knoema.com/ infographics/mctunlb/un-e-government-development-index> accessed 26 January 2021.

99 Amnesty International, Muzzling Dissent Online: Bangladesh (Amnesty International 2018) <https://www.amnesty.org/download/Documents/ASA1393642018ENGLISH.PDF> accessed 26

Page $\mid 130$ 


\section{CONCLUSION}

Bangladesh can learn from the experiences of the advanced democracies and a few developing countries where governance reforms have provided productive outcomes benefiting all who matter--the people, in particular. The several approaches and models outlined above can influence reform thinking and persuade reform strategists to adopt a combination of elements from the most appropriate ones. Whatever option is chosen, building inclusive, effective, accountable and ethical institutions should be the definitive consideration for societal wellbeing and development. Institutions build nations and, thus, must be run sensibly by a corps of well-groomed administrators steered by politicians possessed of acumen, ability and altruism to serve citizens and earn their trust. A truly representative parliament elected freely and fairly can be the instrument for neutralising executive dominance and, along with other agencies of surveillance and control, can contribute to maintaining a sound governance regimen in the country.

In the past decade, some sporadic reforms in a few areas of governance have been evident in Bangladesh. These have been fragmentary and incremental, attempted at irregular intervals, and devoid of any overarching rationale or structured framework. Reform planners and policymakers have generally been unmindful of new ideas or the positive effects of practical solutions to problems elsewhere. Thus, the outcome of reform attempts has been inconsistent and impact unpredictable and perfunctory. The reform phenomenon has touched the fringes rather than the entirety of the governance edifice, leaving crevices and missing links. At the helm, the political leadership can do better by driving governance reform with care, conviction and commitment. The bureaucracy must discard its 'resistant-to-change' baggage and be more forthcoming in supporting innovation and change. Civil society is expected to adopt a more active role as a democratic watchdog and impress upon the government for meaningful reforms, while the external donors attend to the country's contextual needs rather than be overly obtruding. The unfinished governance reform agendas require utmost attention and accelerated action, otherwise the pursuit of sustainable inclusive development will remain stuck in a blind alley.

January 2021; EurAsian Times, 'How the Draconian 'Digital Security Act' of Bangladesh is Muzzling Press Freedom, Secular Voices? (EurAsian Times, 26 May 2020). 